\title{
Correction to: Term birth weight and ambient air pollutant concentrations during pregnancy, among women living in Monroe County, New York
}

\author{
Rui Li ${ }^{1} \cdot$ Philip K. Hopke ${ }^{1} \cdot$ Ann Dozier ${ }^{1} \cdot$ Sally W. Thurston ${ }^{2} \cdot$ Kelly Thevenet-Morrison $^{1} \cdot$ Daniel Croft $^{3}$. \\ Mauro Masiol ${ }^{1} \cdot$ Stefania Squizzato ${ }^{1}$. David Chalupa ${ }^{4} \cdot$ David Q. Rich $^{1,3,4}$
}

Published online: 10 September 2019

(c) The Author(s) 2019. This article is published with open access

\section{Correction to: Journal of Exposure Science \& Environmental Epidemiology \\ https://doi.org/10.1038/s41370-019-0131-8}

We have updated the licence from Standard to Open Access having initially published it with the wrong licence.
Open Access This article is licensed under a Creative Commons Attribution 4.0 International License, which permits use, sharing, adaptation, distribution and reproduction in any medium or format, as long as you give appropriate credit to the original author(s) and the source, provide a link to the Creative Commons license, and indicate if changes were made. The images or other third party material in this article are included in the article's Creative Commons license, unless indicated otherwise in a credit line to the material. If material is not included in the article's Creative Commons license and your intended use is not permitted by statutory regulation or exceeds the permitted use, you will need to obtain permission directly from the copyright holder. To view a copy of this license, visit http://creativecommons. org/licenses/by/4.0/.
The original article can be found online at https://doi.org/10.1038/ s41370-019-0131-8.

David Q. Rich

david_rich@urmc.rochester.edu

1 Department of Public Health Sciences, University of Rochester Medical Center, Rochester, NY, USA

2 Department of Biostatistics and Computational Biology, University of Rochester Medical Center, Rochester, NY, USA

3 Department of Medicine, University of Rochester Medical Center, Rochester, NY, USA

4 Department of Environmental Medicine, University of Rochester Medical Center, Rochester, NY, USA 